\title{
THE EMBRYONIC DEVELOPMENT OF THE INTERSTITIAL CELLS OF LEYDIG.
}

\author{
BY \\ R. H. WHITEHEAD, M. D., \\ Professor of Anatomy, Medical Department, University of North Carolina. \\ From the Hull Laboratory of Anatomy, University of Chicago.
}

With 10 Text Figures.

The interstitial cells of Leydig furnish such a striking feature in the testis of mammalian embryos that one is surprised to find that their development has received very little study. Doubtless this is due to the fact that embryologists in their investigations of the development of the testis have had their attention focused upon the much more important subject of spermatogenesis.

These cells have been known for a long time. Leydig discovered them in 1850, and stated that they were a constant constituent of the mammalian testis. He regarded them as connective-tissue cells, and classed them with fat and pigment cells. This view was adopted by Koelliker in 1854. Boll, 69, observed an intimate relation between them and the blood vessels, and believed that Leydig's cells composed the walls of capillaries. Von Ebner, 7r, studied them in several mammals, and concluded that they were "a peculiar form of connective tissue." $F$. Hofmeister, 72, seems to have been the first to approach the problem of the nature of these cells by a study of embryonic material. Examining the testis of human embryos at four and seven months, he found that Leydig's cells constituted about two-thirds of the bulk of the gland in the embryo of four months, and only about one-tenth in that of a boy about eight years old; at puberty they were greatly increased in number, and contained much fat and pigment. He too regarded the interstitial cells as connective tissue, and thought that he could detect transition forms between them and the fixed connective-tissue cells. Waldeyer, 74, classed them with his plasma cells, but later regarded them as perithelial. Harvey, 75, noticed, as others had done, their resemblance to nerve cells, and advanced the view that they were derived from the sympathetic nervous system. This view, however, has been discredited by all writers on the subject. 
Hansemann ${ }^{1}$ regards it as certain that Leydig's interstitial substance belongs to the connective-tissue group, because he believed he could demonstrate an intracellular substance with Van Gieson's stain. He made the interesting observation that in the hibernating marmot no Leydig's cells were present, and that evidences of spermatogenesis were also lacking during that period; whereas in the waking animal the cells were present in such large numbers as to produce a picture resembling large-celled sarcoma. These observations, together with those of others upon fat and pigment contained in the cells, lead him to conclude that Leydig's cells constitute a distinct organ.

In 1896 , Fr. Reinke ${ }^{2}$ made the discovery of crystalloids in Leydig's cells. He found that these bodies were absent before puberty, present in large number during active sexual life, and again absent in old age.

Von Bardeleben, ${ }^{\text {s }}$ from whose article the references to the earlier literature were taken, studied Leydig's cells in the testes of criminals, the organs being removed immediately after execution. He was impressed by the epithelial appearance of the cells, and noted that the cell-margins were not smooth, but rather serrated-the expression of intercellular bridges connecting adjacent cells. He found no intercellular substance, properly speaking, and no mitotic figures, though frequently he saw evidences of direct division. He thinks that Leydig's cells are almost identical in appearance with the Sertoli cells of the seminal tubules, and believes that they are in fact youthful forms of Sertoli cells. They are capable, he says, of passing through the walls of the tubules, there to become Sertoli cells and take the place of such as are worn out in the performance of their function. In the last analysis, according to him, Leydig's cells are epithelial in nature, and are derived from the germinal epithelium.

J. Plato describes minute canals in the walls of the seminal tubules through which, he thinks, fat and pigment from the interstitial cells stream into the Sertoli cells, to be used as pabulum in spermatogenesis. To support this hypothesis he undertook a study of the development of

\footnotetext{
1 Ueber die grossen $\mathrm{Zwischenzellen} \mathrm{des} \mathrm{Hodens.} \mathrm{Arch.} \mathrm{f.} \mathrm{Anat.} \mathrm{u.} \mathrm{Physiol.,}$ Leipzig, 1895, Physiol. Abth., p. 176.

${ }^{2}$ Beitraege zur Histologie des Menschen. Arch. f. mikr. Anat., Bonn, 1896, Bd. XLVII, p. 34.

${ }^{3}$ Beitraege zur Histologie des Hodens und zur Spermatogenese beim Menschen. Arch. f. Anat. u. Physiol., Anat. Abth., Supplement-Band, Leipzig, 1897, p. 193.

"Die interstitiellen Zellen des Hodens und ihre physiologische Bedeutung. Arch. f. mikr. Anat., Bonn, 1897, Bd. XLVIII, p. 280.
} 
Leydig's cells in cat embryos, ${ }^{5}$ using unstained sections of material fixed in Hermann's fluid. He begins his observations with the embryo of seven weeks, which, we may note, is quite a late stage. Here he finds Leydig's cells in all stages of transition to fixed connective-tissue cells, the transition proceeding from the neighborhood of the blood vessels towards the seminal tubules. He could find but one Leydig's cell containing a mitotic figure. Fat is present only in minute droplets. In the embryo at term the Leydig's cells are in close apposition with the walls of the tubules, and their nuclei are eccentric in position; drops of fat are present in the portion of the cell-body which lies opposite the nucleus. The subalbugineal layer of Leydig's cells is quite thick. In the newborn cat the subalbugineal layer of cells has almost ranished, owing to the increase in length of the tubules. Fat is wanting in many of the cells, which present, therefore, a spongy appearance. $\mathrm{He}$ concludes that Leydig's cells are developed from the connective tissue which accompanies the bload vessels of the testis, somewhat after the manner of typical fat cells, and regards them as trophic nurse-cells ("trophische Huelfzellen"), whose function is to pass their specific inclusions into the seminal tubules.

M. v. Lenhossék ${ }^{8}$ confirms, in the main, the observations of Reinke as to the crystalloids. He is inclined to regard the interstitial cells as epithelial. He thinks that the presence of crystalloids in them and the absence of connective-tissue cells elsewhere in the body similar to them are decided evidence against the opinion which classes them with the connective tissues. He advances the theory that they are unused remains of the germinal epithelium, and that their function is to store up pabulum, which they give over on demand to the seminal tubules.

H. Beissner, in an article intended mainly as a refutation of the opinions of Plato, calls attention to the work of M. Nussbaum in 1880 . The latter held that the nests and strands of Leydig's cells were invested by a membrane similar to the wall of the seminal tubules, so that one might compare them with the Pflueger's tubules of the ovary. He suggested that they were groups of germinal epithelium which had stopped developing at an early stage-a suggestion somewhat like that of $\mathrm{v}$. Lenhossék.

'Zur Kenntniss der Anatomie und Physiologie der Geschlechtsorgane. Arch. f. mikr. Anat., Bonn, 1897, Bd. I, p. 640 .

${ }^{8}$ Beitraege zur Kenntniss der Zwischenzellen des Hodens. Arch. f. Anat. u. Physiol., Leipzig, 1897, Anat. Abth., p. 65.

'Die Zwischenzellen des Hodens und thre Bedeutung. Arch. f. mikr. Anat., Bonn, 1898, Bd. LI, p. 794. 
Among recent text-books of histology, Boehm and Davidoff state that Leydig's cells " are probably remains of the Wolffian body"; Szymonowicz says that we must assume that they are connective tissue.

Thus it appears that there are two principal views as to the histological nature of Leydig's cells. According to the one, they belong to the connective tissues (Leydig, Koelliker, v. Ebner, Hofmeister, Hansemann, Plato); according to the other, they are epithelial cells derived from the germinal epithelium (Nussbaum, v. Bardeleben, v. Lenhossék). It also appears that these views are, in the main, deductions from the study of adult conditions. It is worthy of note that the two investigators who have made a special study of the subject in mammalian embryos, Hofmeister and Plato, both conclude that Leydig's cells are derived from the interstitial tissue of the primitive testis. Their investigations, however, are incomplete, in that they were not made upon a series of embryos extending into the early stages, but upon a few isolated examples in the later stages of development.

As my work upon this subject was nearing its completion, there appeared a preliminary account of a study of the embryology of the ovary and testis by Bennet M. Allen, carried out upon pig and rabbit embryos, in which the following statements are made concerning the interstitial cells: "The connective-tissue elements of ovary and testis are derived from the peritoneum. In early stages they are not distinguishable from the cells which make up the sex-cords, except that the latter are marked off from the stroma by their membrana propria ... the albuginea is largely formed by the actual transformation of the basal parts of the sex-cords into connective-tissue elements. The interstitial cells are characterized by a large nucleus, distinct cell-boundaries, a centrosome and centrosphere, and very granular cytoplasm. They first appear in the stroma of both ovary and testis of the pig of $2.5 \mathrm{~cm}$. length. They are far more numerous in the testis than in the ovary. Their appearance is coincident with that of a large number of fatty globules in the peritoneum and sex-cords. In the testis they persist for a long time. . . . In both organs they divide by mitosis. This process soon ceases in the ovary, while in the testis, on the other hand, division figures are found in the interstitial cells at a stage as late as the $7.5 \mathrm{~cm}$. embryo. In the testis of the $15 \mathrm{~cm}$. embryo they (the interstitial cells) have begun to degenerate. This process manifests itself in a shrinkage of the cyto-

s The Embryonic Development of the Ovary and Testis of the Mammalia. Biological Bulletin of the Marine Biological Laboratory, Woods Holl, Mass., Vol. V, No. 1. 
plasm." "In the ovary of the 85 day rabbit they are very common, their origin from the theca interna of atretic follicles being clearly shown. This, taken in connection with the additional fact that they make their appearance in the $2.5 \mathrm{~cm}$. pig embryo coincident with the fatty degeneration of the germinative cells of the seminiferous tubules and their ovarian homologues, together with that of many cells of the germinal epithelium, would lead us to conclude that cell-degeneration offers the stimulus or condition that brings about the formation of the interstitial cells."

The observations about to be described were made upon pig embryos. The material was fixed principally with Zenker's fluid, and stained with hæmatoxylin and Congo-red, iron-hæmatoxylin and Congo-red, and by Mallory's method for connective tissue. A series was fixed in Flemming's fluid, and studied either stained with iron-hamatoxylin or unstained. Another series was used for frozen sections and staining with Sudan III. Also a few other methods were employed for special purposes.

It should be remarked at the outset that the theory that Leydig's cells are derived from the epithelium of the Wolffian body cannot obtain in the pig; for in this animal Leydig's cells appear before connection has been made between the epithelial constituents of the testis and Wolffian body. Furthermore, in the case of the pig, at least, the tubules of the rete testis grow into the Wolffian body and establish connection with the Bowman's capsules of the glomeruli, and not vice versa. In this connection see also J. B. MacCallum: Notes on the Wolffian Body of Higher Mammals; Amer. Jour. Anat., Balt., Vol. I, No. 3, p. 245; and the article of Allen previously referred to.

As I find myself in accord with the conclusion of Allen, that the interstitial tissue of the testis is derived from the peritoneum, meaning thereby the mesothelium of the genital ridge, I may omit the account of my study of the earlier stages, and proceed to the description of the intertubular tissue of the testis in the pig of 22 or $23 \mathrm{~mm}$., a stage immediately preceding the appearance of Leydig's cells.

In the pig of this length the testis may readily be identified, as the rudiments of the tunica albuginea and the mediastinum are fairly distinct, the primitive seminal tubules are well defined, and their basement membrane is formed. The intertubular spaces in the more central portions of the gland are, on the whole, larger than those near the periphery. In the latter situation they consist mainly of capillaries derived from vessels of the albuginea, whereas in the former case they are as wide as, or even wider, than the tubules, owing to the presence in considerable 
quantity of a loose cellular tissue. The constitution of this tissue is shown very well by Mallory's stain. In sections thus stained (Fig. 1) it is seen to be composed of a mixture of cells and fibrils. The cells often have little or no cytoplasm, some appearing to be mere naked nuclei; but others show a collection of cytoplasm at one pole. The nuclei are spherical or ovoid, except when closely packed together, in which case they incline to the spindle-shape. They contain much nuclear sap in which is a network of chromatin; and usually there is a

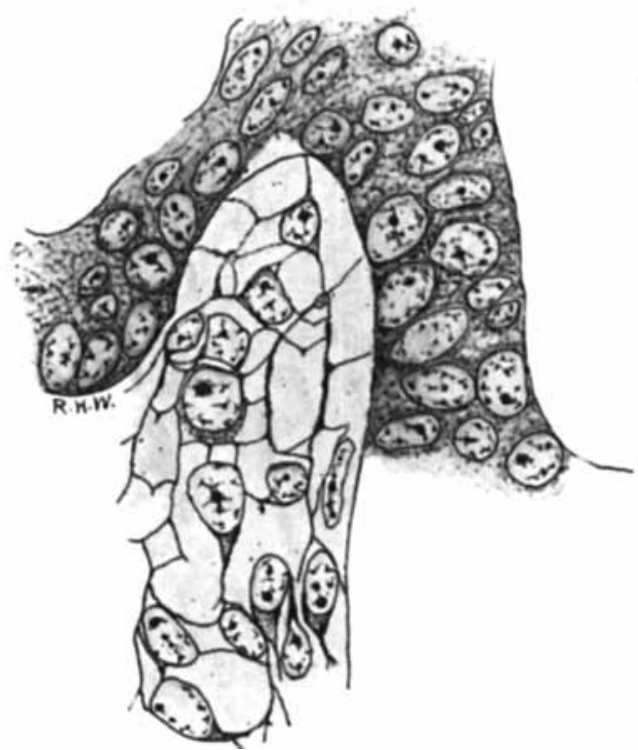

FIG. 1. Pig 22. $m m$. Shows the structure of the intertubular tissue. Mallory's connective-tissue stain. $\times 800$.

quite distinct nucleolus. Mitotic figures are present here and there. The cells or nuclei are imbedded in a network of fibrils which take the aniline-blue of the stain. It seems clear that this tissue is a young connective-tissue syncytium in the sense of Mall.' In all essentials it is quite similar in structure to the deeper layers of the albuginea, with which it is continuous, and to the mesenchyme in general.

Leydig's cells were first definitely encountered in embryos $24 \mathrm{~mm}$. long. In the sections they appear scattered about in the intertubular

' On the Development of the Connective Tissues from the Connective-Tissue Syncytium. Amer. Jour. Anat., Balt., 1902, Vol. I, No. 3. 
spaces, sometimes singly, sometimes in small groups, without any very regular order as regards the other constituents of the testis, except that they are most numerous in the more central intertubular spaces; at this time there are very few, or none at all, immediately under the albuginea. Some of them show mitotic figures. They frequently arrange themselves along the basement membrane of the tubules. In size and shape they vary greatly (Fig. 2); some are spindle-shaped with the nucleus near the center of the spindle; some are oval with the nucleus in the larger end, while at the opposite end the cytoplasm tapers to a process; some are irregularly oval or spindle-shaped, while others are polygonal with eccentric nuclei. The difference in size is due principally to varying amounts of cytoplasm. Their nuclei are quite similar to those of the cells which compose the intertubular tissue of the pig of $22 \mathrm{~mm}$. and stil compose the larger part of it in the pig of $24 \mathrm{~mm}$. The nuclei of the Leydig's cells are perhaps larger and more spherical, and may stain more deeply, but in general they are indistinguishable from those of the other cells in the intertubular spaces. The cytoplasm is very granular, and stains well with acid dyes, so that the cells stand out very distinctly. They are markedly branched. In sections stained with hæmatoxylin and eosin the cell-margins may appear quite smooth; if Congo-red be employed as the cytoplasmic stain, some notion of the branching may be obtained, but Mallory's method for connective tissue shows the branches best (Fig. 2). The branches vary much as to size. It is difficult, frequently, to determine whether they merely interlace with one another or are in actual continuity; in some places, however, the latter relation seems clear enough to justify the conclusion that, at first, Leydig's cells form a syncytium. Figures two and three are taken from rather marked examples of this condition. In addition to thus forming syncytium, some of the processes seem to be continuous with the exoplasmic network of

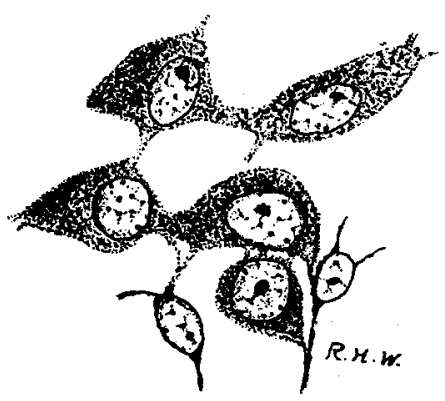

Fig. 2. Pig $24 \mathrm{~mm}$. A group of young Leydig's cells. Mallory $\mathrm{s}$ connective-tissue stain.
$\times 800$.

the fixed connective-tissue cells. Thus practically the only difference between the young "interstitial substance" of Leydig and the intertubular tissue of the preceding stage is the greater amount of cytoplasm possessed by the former; even the syncytial arrangement is retained for a short time. Hence the conclusion is drawn that Leydig's cells are delived from the cells of the intertubular tissue, which, as we haver seen, 
is a mesenchymal structure differing in no essential from the mesenchyme in general.

During the next succeeding stages a number of interesting changes may be noted. The Leydig's cells undergo rapid increase both in number and size, so that they soon come to be the predominating constituent of the intertubular spaces. The fixed connective-tissue nuclei, on the other hand, become smaller and relatively much less numerous. The increase in the number of the Leydig's cells is due, in large measure, to karyokinesis, as mitoses are fairly abundant; but doubtless it is also due, in part, to the continued conversion of mesenchyme cells into Leydig's cells. These cells now begin to assume a fairly typical form; the majority of them are polygonal, and the nucleus, spherical in shape and eccentric in position, contains much chromatin and a large nucleolus. Various other shapes, however, are observed which seem to be due to mechanical conditions. Occasionally they are arranged alongside the tubules, so that the latter in cross section appear surrounded by a sheath

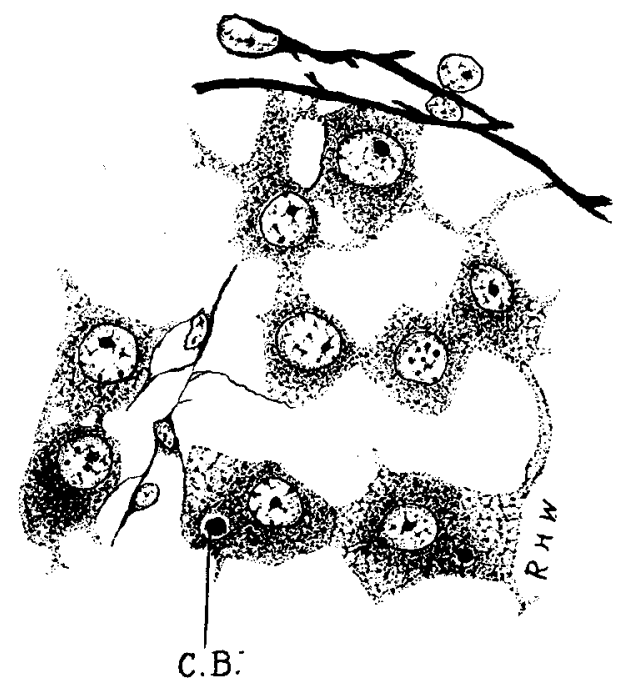

Fic. 3. Pig $3.5 \mathrm{~cm}$. A group of Leydig's cells from just beneath the albuginea. A delicate reticulum is forming. C.B. centrosphere B., ; Mallory's connective-tissue stain. sphere
$\times 800$.

At the stage of $3.5 \mathrm{~cm}$. (Fig. 3) the Iueydig's cells present the greatest size to which they attain in the early embryo, and are very striking objects in preparations made by Mallory's method, which can be used so as to give a fair differential stain. They are very granular, and the of Leydig's cells outside of the basement membrane. Soon after they are first seen in the more central intertubular spaces they begin to make their appearance under the albuginea, where they rapidly increase, particularly large masses being found along the points of attachment of the septa. During this time also the branches begin to disappear, and soon there is no evidence of a syncytial arrangement. This change seems to occur last in the subalbugineal cells; quite a marked branching can sometimes be made out in this situation in even as late a stage as the embryo of $3.5 \mathrm{~cm}$. 
cytoplasmic network is much looser at the periphery of the cell than it is around the nucleus; the meshes of the net seem to have been distended, and the coarse granules are very apparent at the nodal points. As will be seen later, the same appearance, but in a much exaggerated degree, is found in the last stages of the embryonic development of these cells. During this period also the fixed connective-tissue cells begin to build a delicate reticulum (Fig. 3).

Following the stage shown in the embryo of $3.5 \mathrm{~cm}$. there is a progressive decrease in the size of the Leydig's cells, the process affecting

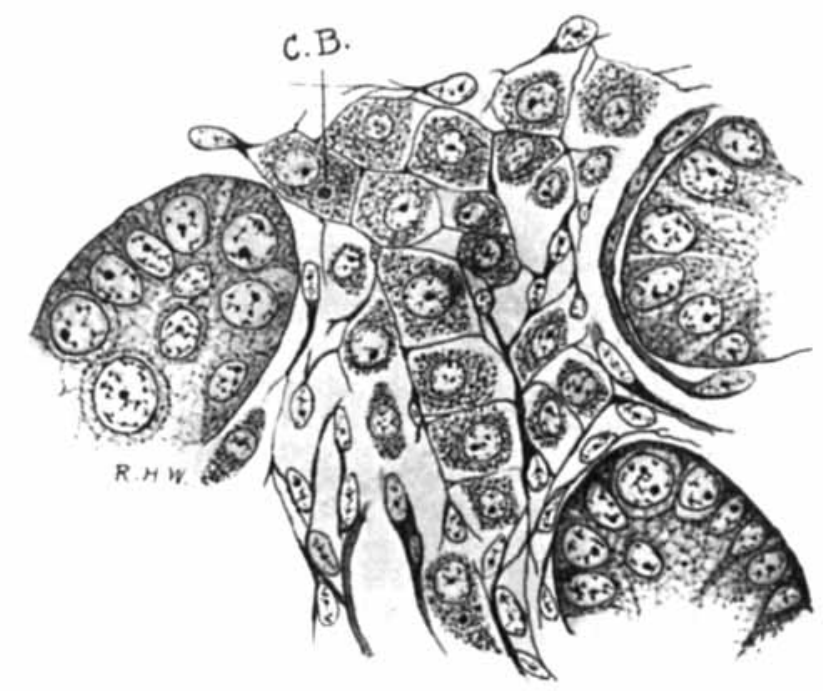

Fra. 4. Pig $5.5 \mathrm{~cm}$. A group of tubules and an intertubular space. A quite perfect reticulum for the Leydig's cells has been formed. C.B., centrosphere B.; Mallary's connective-tissue stain. $\times 800$.

both the cell-body and the nucleus, though the change is more marked in the former (Figs. 4 and 5). There is much condensation of the cytoplasmic network, together with actual disappearance of cytoplasm. This process reaches its acme in the pig of $14 \mathrm{~cm}$ (Fig. 5), where many of the cells are reduced to their primitive condition of almost naked nuclei. This change was noted by Allen (loc. cit.), but the term "degeneration" employed by him scarcely seems appropriate; atrophy would doubtless be a more appropriate term. This atrophy, we shall see, is merely temporary. Very few intertubular spaces can be found which are as wide and contain as many and as large Leydig's cells as the one represented in the figure; they are very scanty also beneath the 
albuginea. Between the tubuli recti, on the other hand, in which situation the intertubular spaces are much wider, they are larger and fairly numerous. A possible explanation of the atrophy of Leydig's cells is

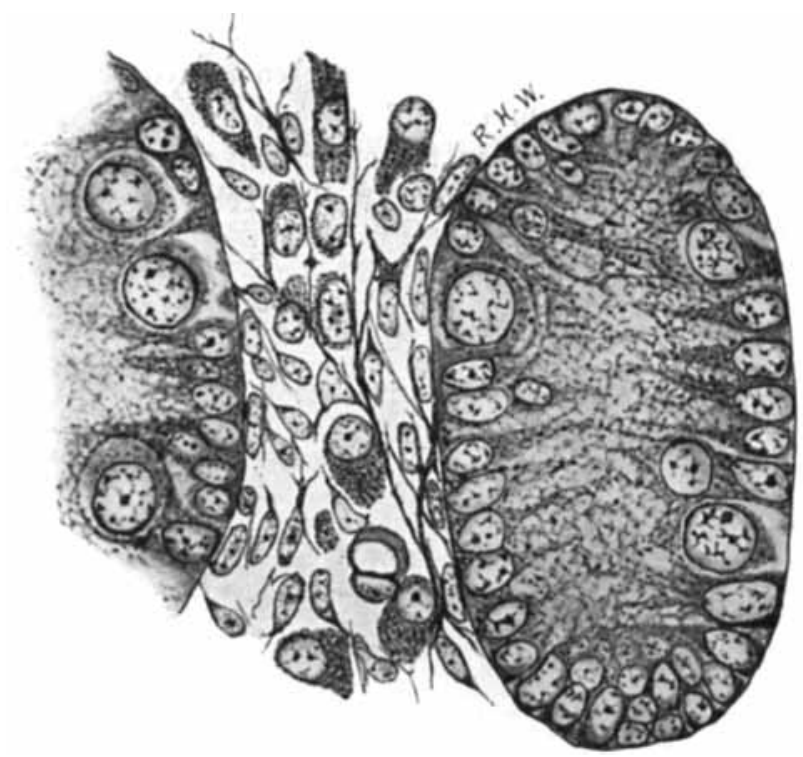

Fra. 5. Pig $14 \mathrm{~cm}$. The tubules are much Iarger, the spaces and the Leydig's cells much smaller than in preceding stages. Mallory's connective-tissue stain. $\times 800$.

suggested by a study of the growth of the seminal tubules. During the time the Leydig's cells are atrophying the tubules are growing rapidly,

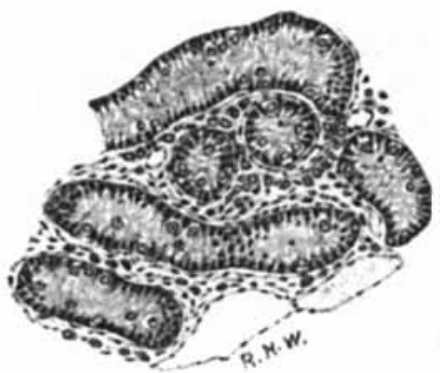

FIG. 6. Pig $14 \mathrm{~cm}$. Tubules and intertubular spaces. Mal-
lory's connectlve-tissue stain. $\times 70$. especially in length, and become markedly convoluted, thus reducing the width of the intertubular spaces, especially of those situated beneath the albuginea (Fig. 6). This, taken in connection with the fact that the cells of the subalbugineal region and in the narrow intertubular spaces are, for the most part, spindle-shaped, would indicate that mechanical pressure exerted by the growing tubules is a possible factor, at least, in the atrophy of the Leydig's cells. On the other hand, it might be argued that the atrophy of the Leydig's cells, by removing a physiological resistance to growth, brings about the increased growth of the tubules.

From the stage of $14 \mathrm{~cm}$. to that of $20 \mathrm{~cm}$. Leydig's cells show little 
appreciable change, and seem to remain passive. After the latter length is passed, however, they enter upon a phase of activity, the most marked histological evidences of which are their great increase in size and extreme vacuolation. As this phase reaches its maximum in the embryo of $28 \mathrm{~cm}$., just before term, I may pass at once to the appearances presented there. A comparison of Fig. 7 with Fig. 6 will serve to show the great change which has taken place as seen under a low power of the microscope. The intertubular spaces are now very wide and packed with large Leydig's cells, which are divided off into lobule-like groups and columns by capillaries. Under the high power (Fig. 8) the cells

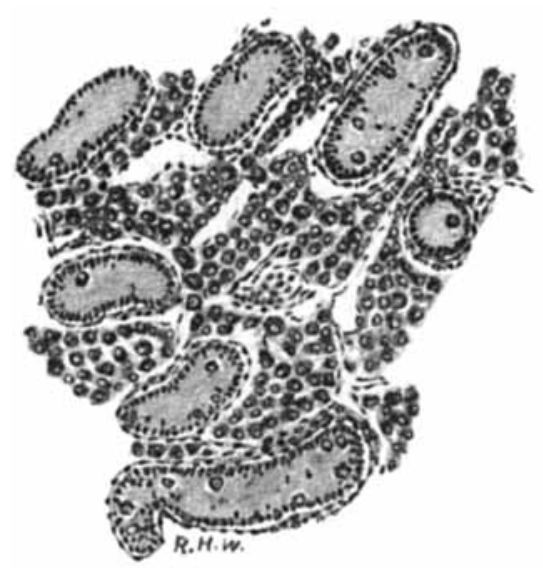

FIG. 7. Pig $28 \mathrm{~cm}$. The intertubular spaces much wider than in figure 6 and packed with large Leydig's cells. Hæmatoxylin and Congo red. $\times 70$. are polygonal with well defined cell-margins, though occasionally these may be indistinct. The nuclei are eccentric in position, and there is a

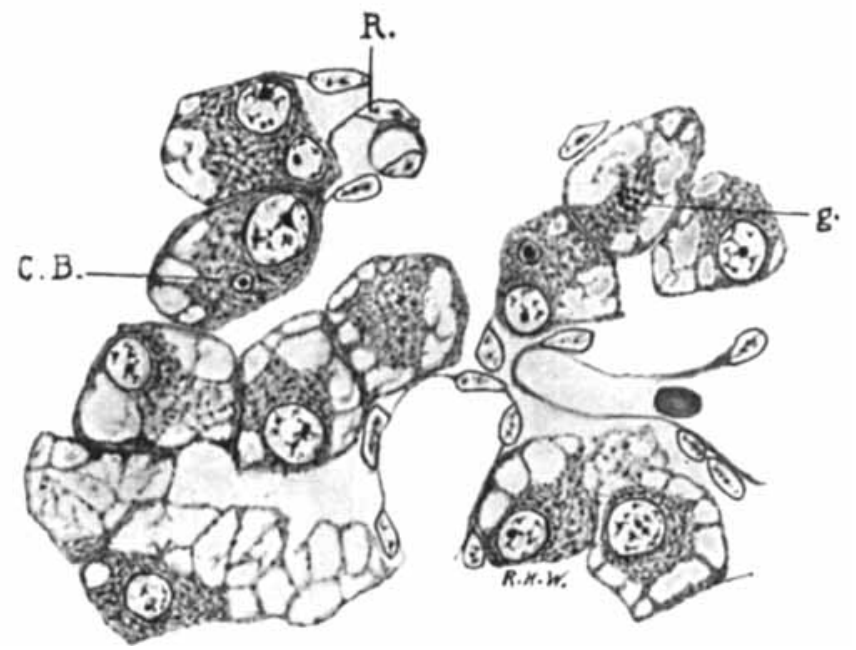

FIg. 8. Pig $28 \mathrm{~cm}$. A.small group of Leydig's cells. g, granules; C.B., centrosphere B. ; $r$, reticulum cells. Mallory's connective-tlssue stain. $\times 800$.

striking difference in the structure of the cytoplasm in different parts of the cell. In the vicinity of the nucleus it is condensed, whereas at the 
periphery, especially on the side opposite to the nucleus, the cytoplasm is extremely vacuolated. Some of the vacuoles may be spherical with smooth boundaries, but many of them are irregular in shape with ragged margins, due to projecting strands of cytoplasm. The vacuoles contain no visible substance in material fixed with Zenker's fluid. Their form alone would almost warrant the conclusion that they are not fat-vacuoles, and the special tests with osmic acid and Sudan III furnish no evidence of fat in them. Cells containing acidophile granules of about the size of the eosinophile granules of certain leucocytes are of not very rare occurrence ( $g$ in Fig. 8 ) ; they are situated in the condensed cytoplasm of the vicinity of the nucleus. Columns of cells are often separated by wide empty spaces, the reticulum is loosened, and one gets the impression that in life the tissue must have been bathed in fluid. The histological appearances suggest a condition, not of degeneration, but rather of active metabolism; the cells which were so greatly atrophied in the pig of $20 \mathrm{~cm}$. have entered here upon a phase marked by increase both of size and of physiological activity. It should be stated here that I was not able to demonstrate mitoses in the Leydig's cells of pigs longer than $7 \mathrm{~cm}$., nor could I feel sure that they multiply by direct division; so that I shall have to leave open the question whether or not new Leydig's cells are formed in the later stages by cell-division. I do not think, however, that there is any doubt but that the atrophied cells found in the pig of $20 \mathrm{~cm}$. are quite able to develop into the large cells of the pig at $28 \mathrm{~cm}$; for the steps of the process can easily be followed in a series of embryos. In this connection we may recall the finding of Hansemann (loc. cit.) in the marmot.

Observations on the Centrospheres.-In the early stages Leydig's cells present two structures in their cytoplasm with great regularity and.constancy (Fig. 9). One of them (C.A. in the

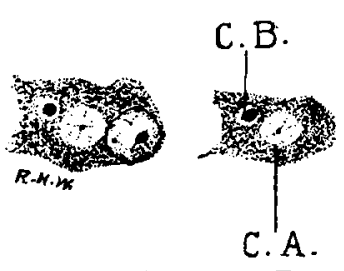

FiG. 9. Pig $2 y$ mm. Two I.eydig's cells. $C$. B., centrosphere B;C.A., centrossphere A; Mallory's connective-tissue staln. $\times 800$. $i_{\imath}$ several particulars. The sphere is smaller, but the central body is many times larger than that of the first structure. With the highest 
power of the microscope at my command, the sphere contains no radiations, though sometimes there are a few minute grains in the clear space around the central body. The latter, as was said, is much larger than that of the first sphere; it is not homogeneous, but seems to be constituted by an aggregation of granules. Its outline frequently is circular, but often it is irregular and its periphery uneven, and its size is variable. This sphere is almost always at some distance from the nucleus, though when it alone is found in a cell, it may be near the nucleus. The central bodies of both spheres stain with iron-hæmatoxylin; also Mallory preparations show them quite clearly, and they are readily made out in unstained sections of Flemming material. The great majority of Leydig's cells seen in the early stages present one or the other of these structures, and a great many of them show both at the same time, so many, indeed, that I think both may be regarded as normal constituents. Their morphology, staining reactions and constancy make it possible that both are centrospheres, and I shall call them such. The point, however, which I should like to emphasize is that the first structure-the large sphere with the small centrosome-is not permanent, but soon disappears; it could not be found in embryos of greater length than $3 \mathrm{~cm}$. The second centrosphere, however, persists, and is found in all the succeeding stages of embryonic development (Figs. 3, 4, 8); even in the atrophied cells of the pig at $14 \mathrm{~cm}$. they still can be demonstrated. In the later stages, however, the centrosome often seems smaller, more homogeneous, and more regularly circular in outline (Fig. 8); the sphere is usually smaller and its wall more homogeneous in appearance, so that the whole structure somewhat resembles a vacuole with a hyaline content.

The Occurrence of Fat.-The occurrence of fat in the seminal tubules and Leydig's cells of various mammals has been noted by several observers. Allen (loc. cit.) bases a theory upon the presence of fat in the primitive seminal tubules and germinal epithelium, suggesting that fatty degeneration of these cells may furnish a "stimulus or condition which brings about the formation of the interstitial cells."

For the study of this subject I used material fixed in Flemming's solution, employing unstained sections as well as sections stained with iron-hæmatoxylin. Owing to the doubts which have been raised as to the reliability of osmic acid as a test for fat, the results thus obtained were controlled by frozen sections stained with Sudan III. In the germinal epithelium of pigs from $2 \mathrm{~cm}$. to $4 \mathrm{~cm}$. it was not possible to demonstrate any fat with either osmic acid or Sudan III. In all these 
stages there are many cells of the germinal epithelium loaded with large granules, but as will be seen later, they certainly are not fat.

With respect to the primitive seminal tubules it was found that sections of Flemming material, stained with iron-hæmatoxylin, showed many black particles, whereas the same material unstained showed very few, or none at all, until the length of $3.5 \mathrm{~cm}$. was reached. It was not until a still later stage was reached that fat could be demonstrated with Sudan III. Making allowances for imperfection of technique, it hardly seems possible that fat could have been present in such large quantity as to constitute a veritable fatty degeneration, and have escaped detection by both the osmic and the Sudan III, especially as each reagent gave good results in later stages. In the light of recent studies of fat metabolism the presence of some fat in these cells would not seem pathological. In pigs of $8 \mathrm{~cm}$. fat is present in the seminal tubules in the form of quite distinct globules, and remains present in that shape through all the remaining stages of their embryonic development.

In the case of the Leydig's cells I could not positively demonstrate a fatty content in pigs under $14 \mathrm{~cm}$. in length. Small globules of fat appear a little later, and are fairly abundant in the Leydig's cells of the $28 \mathrm{~cm}$. embryo. In all cases they are minute droplets situated in the vicinity of the nucleus, and not in the vacuoles previously described. It may be noted here that Plato (second reference) found very little fat in the Leydig's cells of the wild boar.

The Granules of the Germinal Epithelium.-As previously stated, many of the cells which compose the germinal epithelium in pigs of the

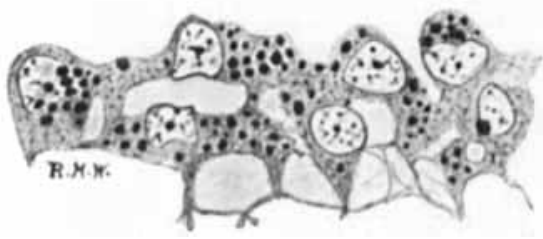

FIG. 10. Pig $25 \mathrm{~mm}$. Peritoneal epithelium with granules. Iron hæmatoxylin and Congo red. $\times 800$. various lengths from $2 \mathrm{~cm}$. to $4 \mathrm{~cm}$. are loaded with large granules (Fig. 10). While they were first noticed in sections prepared by Mallory's method, they are quite distinct in all the different methods employed. In unstained sections they appear as colorless, homogeneous, glistening, more or less circular bodies. They are unaffected by agents which dissolve fat, such as ether and absolute alcohol. In preparations stained with ironhæmatoxylin they appear intensely black. They also stain well with the aniline-blue in Mallory's method, and in general are acidophile, though they can be stained faintly by gentian violet in Weigert's method for fibrin. Occasionally a group of them is seen in a cell which has wandered down from the germinal epithelium into the albuginea; 
and once, in a pig of $3.5 \mathrm{~cm}$., a small collection was seen in a Leydig's cell just beneath the albuginea. They are not yolk granules, for they do not stain with osmic acid, and no similar granules are seen in the cœlomic epithelium elsewhere. A probable explanation of their nature is furnished by the changes which occur in the germinal epithelium at this time. Its cells become vacuolated, and are soon reduced to the squamous cells which cover the tunica vaginalis. So that the granules found in the cells while these changes are going on are probably the products of a hyaline degeneration of the cytoplasm.

\section{SUMMARY.}

The intertubular tissue of. the testis of the pig embryo in stages immediately preceding the appearance of Leydig's cells is a mesenchymal structure derived from the mesothelium of the genital ridge. Histologically, it is a connective-tissue syncytium, consisting of cells and an exoplasmic network of fibrils. The cells are scarcely more than naked nuclei, though some have a small collection of cytoplasm at one pole (Fig. 1).

From the cells of this tissue Leydig's cells are developed by 'growth of cytoplasm. At first they are markedly branched; some of the branches are connected with the general exoplasmic network, while others unite with one another to form a network, so that the cells retain the syncytial arrangement of their ancestors (Figs. 2 and 3). They increase in number and size very rapidly, and soon lose their branches. At first they may have various sizes and shapes, but one form soon predominates. Such a typical Leydig's cell is polygonal, its cytoplasm is very granular, and its nucleus is eccentric and contains a large nucleolus. Mitotic figures can be seen in all the earlier stages.

Leydig's cells pass through two phases of growth, between which a phase of atrophy intervenes. Growth is very rapid from their appearance in the embryo $2.4 \mathrm{~cm}$. long until the length of $3.5 \mathrm{~cm}$. is reached. This is followed by the phase of atrophy, during which the cells return almost to their first state of nearly naked nuclei (Figs. 4 and 5). This process reaches its acme in the embryo $14 \mathrm{~cm}$. long. Synchronous with it there is extensive growth of the seminal tubules, particularly in length, so that they are much convoluted, and the intertubular spaces are correspondingly narrowed (Fig. 6). In the embryo $20 \mathrm{~cm}$. long the cells enter upon the second phase of growth, which attains its maximum in the pig of $28 \mathrm{~cm}$., very near to term. Here the cells are enormously increased in number and size, so that they constitute the predominating 
feature of the microscopic picture (Fig. 7). The nucleus is eccentric in its position; around it the cytoplasm is condensed, while at the periphery of the cell, especially at the opposite pole from the nucleus, it is extensively vacuolated (Fig. 8). Many of these vacuoles are irregular in shape with ragged margins, and none of them contain fat. The appearance of the cells suggests that they have been bathed in fluid.

In unstained sections of material fixed in Flemming's fluid no darlbrown particles were observed in the seminal tubules of pigs of less length than $3 \mathrm{~cm}$; with Sudan III no fat could be demonstrated in the tubules of pigs of less length than $8 \mathrm{~cm}$., after which stage it was constantly present in the shape of globules. The germinal epithelium contains no appreciable amount of fat, the granules observed there being of an entirely different nature. We conclude, therefore, that there is no fatty degeneration of the seminal tubules and germinal epithelium in the early stages of the development of the pig's testis, and that, consequently, the hypothesis which attributes the growth of Leydig's cells to fatty degeneration in these situations is incorrect.

No fat could be demonstrated with osmic acid or Sudan III in Leydig's cells of embryos shorter than $14 \mathrm{~cm}$. After this stage it was found in the shape of minute droplets situated in the cytoplasm near the nucleus, but not in the large vacuoles.

In the young Leydig's cells two structures are found, which, from their morphology and staining reactions, may be classed as centrospheres (Fig. 9). Never more than one of each kind is present in the same cell, but the same cell often contains both at the same time. The large sphere with the small centrosome is soon lost, while the small sphere with the large centrosome persists through the whole period of embryonic development, though it undergoes certain changes in the late stages.

In pigs from $2 \mathrm{~cm}$. to $4 \mathrm{~cm}$. long many cells of the germinal epithelium are loaded with large granules (Fig. 10). They are hyaline material, resulting from a hyaline degeneration of the cytoplasm of the cells during their conversion into the squamous cells of the tunica vaginalis. 